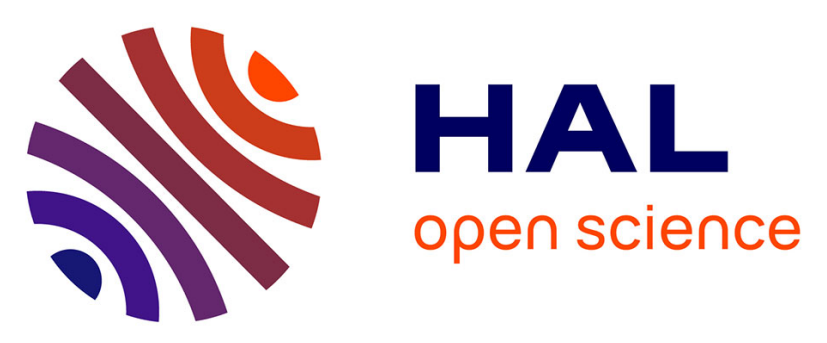

\title{
The altitudinal mobility of wild sheep at the Epigravettian site of Kalavan 1 (Lesser Caucasus, Armenia): evidence from a sequential isotopic analysis in tooth enamel
}

Carlos Tornero, Marie Balasse, Adrian Balasescu, Chataigner Chataigner, Boris Gasparyan, Cyril Montoya

\section{To cite this version:}

Carlos Tornero, Marie Balasse, Adrian Balasescu, Chataigner Chataigner, Boris Gasparyan, et al.. The altitudinal mobility of wild sheep at the Epigravettian site of Kalavan 1 (Lesser Caucasus, Armenia): evidence from a sequential isotopic analysis in tooth enamel. Journal of Human Evolution, 2016, 10.1016/j.jhevol.2016.05.001 . halshs-01473156

\author{
HAL Id: halshs-01473156 \\ https://shs.hal.science/halshs-01473156
}

Submitted on 2 Apr 2020

HAL is a multi-disciplinary open access archive for the deposit and dissemination of scientific research documents, whether they are published or not. The documents may come from teaching and research institutions in France or abroad, or from public or private research centers.
L'archive ouverte pluridisciplinaire HAL, est destinée au dépôt et à la diffusion de documents scientifiques de niveau recherche, publiés ou non, émanant des établissements d'enseignement et de recherche français ou étrangers, des laboratoires publics ou privés. 


\section{The altitudinal mobility of wild sheep at the Epigravettian site of Kalavan 1 (Lesser Caucasus, Armenia): Evidence from...}

Article in Journal of Human Evolution · August 2016

DOI: 10.1016/j.jhevol.2016.05.001

CITATION

1

6 authors, including:

\section{Adrian Balasescu}

Muzeul Naţional de Istorie a României

138 PUBLICATIONS 429 CITATIONS

SEE PROFILE

\section{Boris Gasparyan}

National Academy of Sciences of Armenia 49 PUBLICATIONS 239 CITATIONS

SEE PROFILE
READS
Chataigner C.

French National Centre for Scientific Research 75 PUBLICATIONS 520 CITATIONS

SEE PROFILE

\section{Cyril Montoya}

Ministère de la culture et de la communication 28 PUBLICATIONS 100 CITATIONS

SEE PROFILE

Some of the authors of this publication are also working on these related projects:

ECHOES OF THE PAST REFLECTED IN THE PRESENT ... AN ATTEMPT TO RECONSTRUCT THE NEOLITHIC SOCIETY THROUGH EXPERIMENTAL ARCHEOLOGY View project

“Producción animal y cerámica en el Neolítico peninsulñar. Estudio biogeoquímico integrado del consumo y las prácticas culinaria" (Proyecto I+D HAR2014-60081-R) View project 


\title{
The altitudinal mobility of wild sheep at the Epigravettian site of Kalavan 1 (Lesser Caucasus, Armenia): Evidence from a sequential isotopic analysis in tooth enamel
}

\author{
Carlos Tornero a, *, Marie Balasse ${ }^{\text {a }}$, Adrian Bălăşescu ${ }^{\text {b }}$, Christine Chataigner ${ }^{\text {, }}$ \\ Boris Gasparyan ${ }^{\mathrm{d}}$, Cyril Montoya ${ }^{\mathrm{e}}$ \\ a Archéozoologie, Archéobotanique: Sociétés, Pratiques et Environnements, UMR 7209 CNRS/MNHN, CP56. 55, Rue Buffon, 75005 Paris, France \\ ${ }^{\mathrm{b}}$ National Museum of Romanian History, Calea Victoriei nr.12, Sector 3, 030026 Bucharest, Romania \\ c Archéorient UMR 5133 CNRS, Maison de l'Orient et de la Méditerranée, Jean Pouilloux, 7 rue Raulin, 69365 Lyon, France \\ d Institute of Archaeology and Ethnography, National Academy of Sciences of Republic of Armenia, Armenia \\ e Aix Marseille Université, CNRS, MCC, LAMPEA UMR 7269, 13094 Aix-en-Provence, France
}

\section{A R T I C L E I N F O}

Article history:

Received 9 May 2015

Accepted 1 May 2016

Keywords:

Vertical mobility

Mouflon

Stable carbon and oxygen isotopes

Bioapatite

Upper Paleolithic

Northeastern Armenia

\begin{abstract}
A B S T R A C T
Kalavan 1 is an Epigravettian hunting campsite in the Aregunyats mountain chain in northeastern Armenia (Lesser Caucasus). The site lies at an elevation of $1640 \mathrm{~m}$ in a bottleneck that controls the descent into the Barepat Valley from the alpine meadows above. The lithic and faunal assemblages show evidence of the production of hunting weapons, the hunting and targeting of wild sheep (Ovis orientalis), and the constitution of animal product reserves. A seasonal occupation of the site was proposed within a model of occupation by Epigravettian hunter-gatherers that involved a search for obsidian resources in high altitude sources from the spring to the summer and settling at Kalavan 1 at the end of summer or during autumn to coincide with the migration of wild herds from the alpine meadows to the valley. A key parameter of this model is wild sheep ethology, with a specifically seasonal vertical mobility, based on observations from contemporary mouflon populations from the surrounding areas. In this study, the vertical mobility of Paleolithic wild sheep was directly investigated through sequential isotope analysis $\left(\delta^{18} \mathrm{O}, \delta^{13} \mathrm{C}\right)$ in teeth. A marked seasonality of birth is suggested that reflects a physiological adaptation to the strong environmental constraints of this mountainous region. Most importantly, a recurrent altitudinal mobility was demonstrated on a seasonal basis, which confirms that wild sheep migrated from lowland areas that they occupied in the winter and then moved to higher altitude meadows during the summer. Last, low inter-individual variability in the stable isotope sequences favors a hypothesis of accumulation for these faunal remains over a short time period. Overall, this new dataset strengthens the previous interpretations for Kalavan 1 and contributes to an understanding of the pattern of occupation of mountain territories by Epigravettian communities.
\end{abstract}

() 2016 Elsevier Ltd. All rights reserved.

\section{Introduction}

The open-air site of Kalavan 1 is located at an altitude of $1640 \mathrm{~m}$ in the Aregunyats mountain chain on the north shore of Lake Sevan (1900 m altitude) (Fig. 1). The Paleolithic occupation was established on a late glacial alluvial terrace in the valley of the Barepat (a

\footnotetext{
* Corresponding author.

E-mail addresses: ctornero@mnhn.fr (C. Tornero), balasse@mnhn.fr (M. Balasse), abalasescu2005@yahoo.fr (A. Bălășescu), christine.chataigner@mom.fr (C. Chataigner), borisg@virtualarmenia.am (B. Gasparyan), cyril.montoya@culture.gouv.fr (C. Montoya).
}

tributary of the Aghstev River), at the base of a mountain slope. The excavations at Kalavan 1 revealed an Early Bronze Age necropolis (Kura-Arax culture) at the top of the stratigraphy along with Upper Paleolithic layers at the base. Over $40 \mathrm{~m}^{2}$ of these Epigravettian layers have been explored over the course of several excavations (from 2006 to 2009). The occupation layer 7d3, which is dense in remains and structures, provided nearly 5400 artifacts for which over half $(56.8 \%)$ are remains from hunted fauna. Seven homogeneous AMS dates placed the occupation(s) at approximately 14,000 BP [15,966-14,506 cal BC (2 sigma)] (Montoya et al., 2013; Gasparyan et al., 2014). 


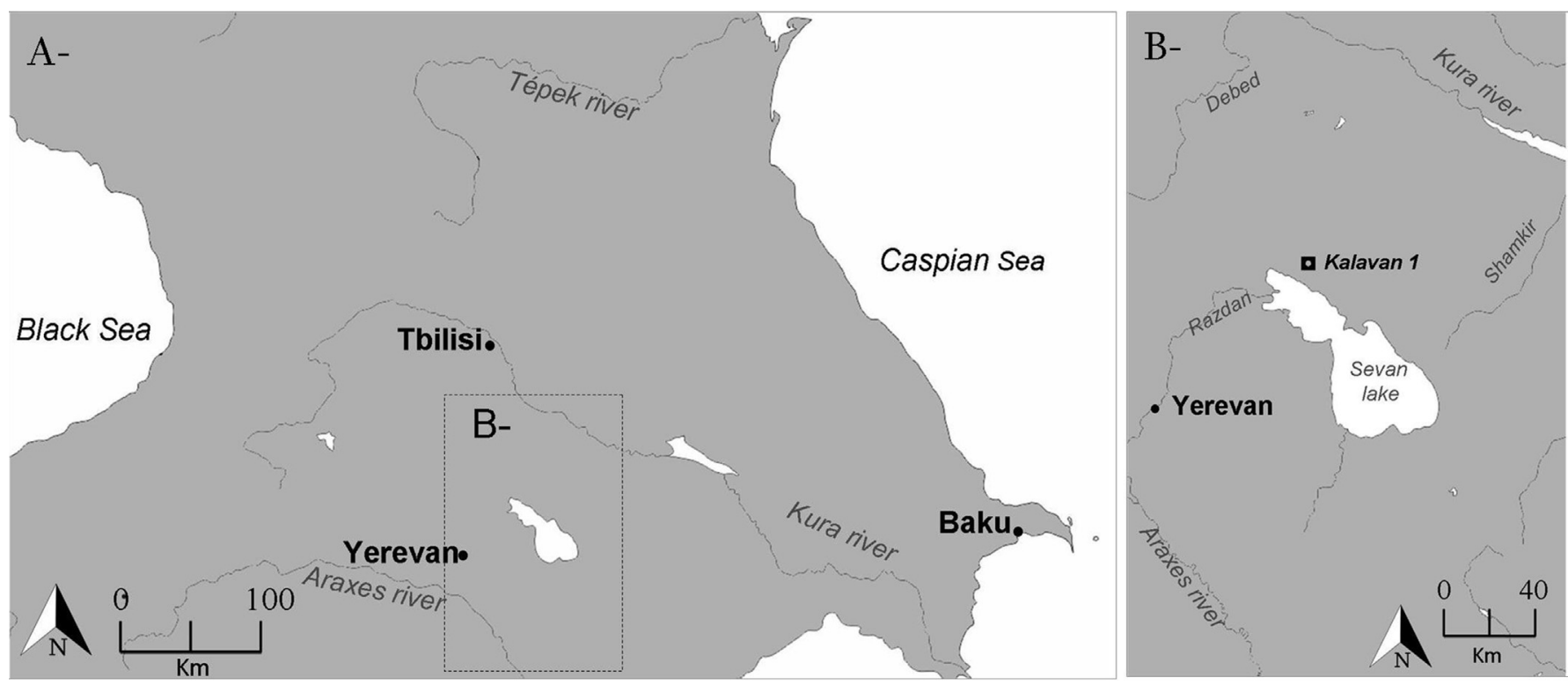

Figure 1. Map showing the location of the Kalavan 1 site in Lesser Caucasus.

Lithic and zooarchaeological analyses documented specialized hunting activity. Of over 3000 faunal remains that have been analyzed to date from layer 7 , all belong to mammals, among which over $18 \%$ are caprinae, and over $80 \%$ are undetermined mediumsized mammals of similar size to the caprinae, although other species could be represented within this category, such as wild boar, wolf, or roe deer. Among the caprinae, Ovis dominate Capra $(\mathrm{NR}=31 / 1)$. The wild sheep remains most probably belong to Ovis orientalis gmelini, the Armenian mouflon. The caprinae mortality profile (161 teeth) shows a predominance of mature specimens (age classes D to G, 1-6 years [Payne, 1973]) and includes no very young animals (age classes A: $0-2$ months and B: 2-6 months) (Montoya et al., 2013). When we include only the wild sheep, the mortality profile (80 teeth) shows a similar tendency. This mortality may reflect the intentional selection of prey of maximum weight. However, the very poor state of preservation of the material could also produce a bias against the youngest animals. Sex ratios could not be determined due to the absence of diagnostic elements in the assemblage. Although some elements of the axial skeleton were under-represented in the assemblage, the presence of the main anatomical parts of the animals suggests hunting activity near the site (Montoya et al., 2013; Bălășescu et al., 2016).

The study of the lithic "chaîne opératoire" sheds light on the management of lithic raw material and hunter gatherers' socioeconomic behavior. The Paleolithic group acquired obsidian from sources that are located to the west and the south of Lake Sevan, at high elevations (1500 m to nearly $3000 \mathrm{~m}$; Fig. 1; Chataigner and Gratuze, 2014a,b). These deposits were accessible only after the snowmelt, during the mildest season (the end of spring to the end of summer). Judging by their size and weight, most of the obsidian blades were probably produced directly by or near the raw material sources. This seems to be confirmed by the absence of any lithic sub-products of the chaîne opératoire of the blades at Kalavan 1 . However, some small blocks of obsidian with blade toolkits were introduced at the site. These small blocks of obsidian, in addition to some local raw materials, were dedicated to the production of bladelets for hunting weaponry (backed bladelets and microgravettes). Treatment of animal skins at the site is suggested by the presence of an ochred area in association with a concentration of stone tools (end scrapers) that are usually devoted to this task (Montoya et al., 2013; Bălăşescu et al., 2016).

Over all, the faunal assemblage and the whole lithic collection that has been recovered at Kalavan 1 reflect the production of hunting tools, the hunting and targeting of wild sheep and the butchering of caprinae carcasses to provide animal products (meat and skin). This Paleolithic occupation most likely occurred specifically at the time of the wild sheep migrations through the Barepat Valley.

A key parameter of this model is wild sheep ethology - more specifically, their vertical mobility. Today, the Armenian mouflon's distribution is limited to northwestern Iran and the Zangesur mountains that define the border between Nakhchivan (Azerbaidjan) and southern Armenia (Syunik province [Valdez, 2008; Khorozyan et al., 2009; Talibov et al., 2009]). The Armenian mouflon preferentially lives in open spaces, inhabiting medium to high altitude mountain steppes and grasslands, with vertical mobility tuned to the seasonal cycle: the winter is spent in the midlands to lowlands, while in the summer, most individuals move to high elevation alpine meadows. It is likely that the present day Armenian mouflon has been gradually moved from the lowlands to middle slope elevation pastures due to the increasing presence of livestock, which has led to competition for space and overgrazing (Talibov et al., 2009). It is supposed that wild sheep were hunted at Kalavan while spending winter under milder conditions at lower elevation sites in the Kura River Basin, below 500 m altitude. The spring migration towards the alpine meadows could have led them through the Agstev River Valley, which is connected to the Getik River Valley and the Barepat Valley, where Kalavan 1 is situated (Fig. 2). At the campsite, located at an intermediate elevation in a bottleneck on the way from the valley to the alpine meadows, the hunting of wild sheep could have occurred either at the time of the spring or the autumn migration (upward and downward migration, respectively). The autumn migration would have provided the hunters with fatter animals with higher quality skin.

The model for the wild sheep altitudinal mobility builds on observations of modern populations and implies similar vertical movements for the late Pleistocene wild sheep. This prerequisite can be directly tested on the archaeological specimens themselves, 


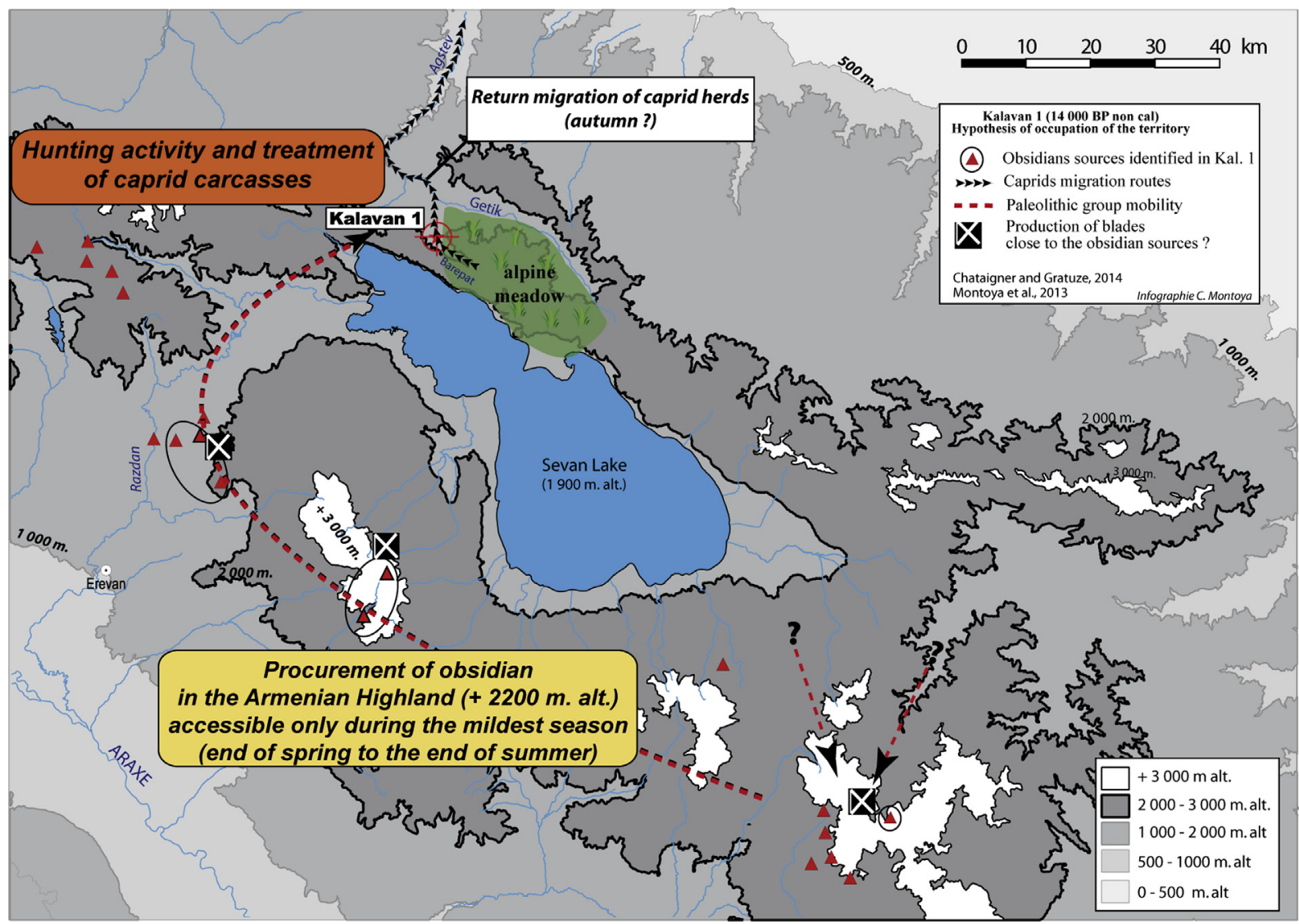

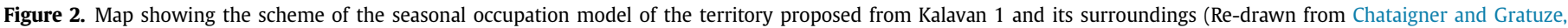
2014a,b) ( ${ }^{\oplus}$ Computer graphics C. Montoya).

through sequential stable isotope analysis of tooth enamel. The objective of this study is to determine whether the stable isotopic signals that were retrieved from the wild sheep teeth from Kalavan 1 could be interpreted in terms of paleoethology, focusing particularly on mobility. The site of Kalavan 1 provides unique evidence for a human re-colonization of the Lesser Caucasus high mountains after the Last Glacial Maximum. Any information that is related to the wild game ethology and environment would be valuable in documenting the subsistence strategy of these Upper Paleolithic hunter-gatherers.

\section{Principles}

A sequential analysis of stable oxygen and carbon isotope compositions of enamel was performed on wild sheep dental remains. Because enamel is not remodeled after the completion of mineralization, this protocol allows for the reconstruction of individual stable isotope histories over the time of tooth formation. In sheep, the formation of the second and third molars covers over two years in early life (Weinreb and Sharav, 1964). Stable oxygen and carbon isotopes are incorporated into the enamel through eating and drinking (Land et al., 1980; Lee-Thorp and van der Merwe, 1987). They are inherited from the plants and water in the ecosystem, whose $\delta^{13} \mathrm{C}$ and $\delta^{18} \mathrm{O}$ values depend on environmental and climatic factors, some of which may be influenced by seasonality (Rozanski et al., 1993; Kohn et al., 1996; Kohn and Welker, 2005). These signals thus help us to assess mobility on a seasonal scale.
The oxygen isotope ratios in the mineral fraction of vertebrate skeletons are linked to that of body water. The oxygen isotope composition of body water results from the balance between ingested water (mainly drinking water in the case of the Armenian mouflon) and water that is lost during excretion and transpiration. In large mammals from temperate Europe, $\delta^{18} \mathrm{O}$ values in skeleton bioapatites are strongly related to that of local meteoric water (Land et al., 1980; D'Angela and Longinelli, 1991), the oxygen isotopic composition of which is affected by climatic and geographic factors, including ambient temperature and altitude. At high and middle latitudes, at a given location, seasonal changes in ambient temperature lead to higher $\delta^{18} \mathrm{O}$ values in meteoric water during the warmer seasons and lower $\delta^{18} \mathrm{O}$ values during the colder seasons (Gat, 1996).

Considering the hypothesis of vertical mobility for wild sheep, the altitude effect should also be taken into account, with increasingly low $\delta^{18} \mathrm{O}$ values as elevation gets higher, due to a gradual removal of moisture from uplifted air masses with a preferential removal of ${ }^{18} \mathrm{O}$ during condensation (Rozanski et al., 1993). The gradients in precipitation $\delta^{18} \mathrm{O}$ values versus altitude vary according to local conditions on the order of $1-3 \% / \mathrm{km}$ (Gonfiantini et al., 2001; Longinelli and Selmo, 2003). Additionally, at high elevation sites, melt water from surface snow (accumulated over winter at the time of the year when $\delta^{18} \mathrm{O}$ values are the lowest) and also potentially from glacial ice (deposited in colder times over the Last Glacial Maximum and with considerably lower $\delta^{18} \mathrm{O}$ values [Bhatia et al., 2011]), would provide wild sheep with ${ }^{18} \mathrm{O}$-depleted water in spring and summer (Fisher and Valentine, 2013). Consequently, the expected vertical trajectories of wild sheep with 
summer pasturing in the highlands and wintering in lowlands could counterbalance seasonal trends in $\delta^{18} \mathrm{O}$ values at the local scale, leading to a reduction of the annual amplitude of variation in $\delta^{18} \mathrm{O}$ values that are recorded in tooth enamel on an annual scale. The likelihood of these effects leading to a reversal of the pattern of seasonal variations in $\delta^{18} \mathrm{O}$ values on an annual scale, with the lowest $\delta^{18} \mathrm{O}$ values corresponding to summer and the highest to winter, is difficult to evaluate given the uncertainties in (1) the relative contribution of the different potential water sources at high elevation sites - spring/summer precipitations, snow melt, glacial ice melt, (2) and how much those would be ${ }^{18} \mathrm{O}$-depleted compared to water sources in the valley in winter.

Carbon isotopes in enamel bioapatite reflect $\delta^{13} \mathrm{C}$ values of food plants (Lee-Thorp and van der Merwe, 1987; Cerling et al., 1993). Wild sheep are mainly grazers, although they may also feed on shrubs. The grassy component in their diet should reflect changes between summer and winter ranges, even though the plants' relative availability may be biased by food preferences. At the time of occupation of Kalavan 1, in the prevailing cold and dry conditions of the Late Glacial period, the site was surrounded by a steppe environment (Montoya et al., 2013). Only $C_{3}$ plants are expected in the subalpine and alpine meadows. Today, the dry steppe to semidesert environments of the Kura Valley provide habitats to many $\mathrm{C}_{4}$ plants (R. Hovsepyan, pers. comm). $\mathrm{C}_{4}$ grasslands have also been documented in the lowlands of northeastern (Akhani and Ziegler, 2002; Akhani and Ghasemkhani, 2007) and northwestern Iran (Hatami and Khosravi, 2013). In these areas, the presence of $C_{4}$ Chenopodiaceae has been identified until late autumn although the proportion of $\mathrm{C}_{4}$ plants dramatically drops in the winter, some may survive on protected parts of the ground and between rocks. The occurrence of $\mathrm{C}_{4}$ plants in the region in the Late Glacial time is unknown. Although $\mathrm{C}_{4}$ ecosystems existed during the Last Glacial Maximum on a global scale (at a time when they were favored by climate and reduced $\mathrm{CO}_{2}$ levels [Ehleringer, 2005]), favorable pluviometric and temperature conditions for the development of $\mathrm{C}_{4}$ plants were essentially found at low latitudes. In the middle latitudes, inversely, the relative abundance of $\mathrm{C}_{4}$ plants increased from the Last Glacial Maximum to the Holocene - during the Late Glacial period - concomitantly with the increase in temperature (Rao et al., 2012). Therefore, although it is not expected that the availability of $\mathrm{C}_{4}$ plants would have been higher at the time of occupation of Kalavan 1, whether it was similar to the present day or significantly lower is difficult to determine.

In modern environments, $C_{3}$ and $C_{4}$ plants have $\delta^{13} \mathrm{C}$ values averaging, respectively, 26.5\% (Kohn, 2010) and $-12.5 \%$ (Vogel et al., 1978; Winter, 1981). These $\overline{\delta^{13} \mathrm{C} \text { values must be corrected for }}$ the fossil fuel effect when they are applied to pre-industrial ecosystems ( $+1.5 \%$; Friedli et al., 1986; Marino and McElroy, 1991). Moreover, both atmospheric $\mathrm{CO}_{2}$ concentrations and $\delta^{13} \mathrm{C}$ values rose from the last glacial period to the Holocene (Marino et al., 1992). In Western Europe, the residual effect led to higher $\delta^{13} \mathrm{C}$ values for plants by $1.5-3 \%$ in the last glacial period (Hatté et al., 1998). In Late Glacial time, within the transitional phase between full glaciation and the Holocene, the amplitude of this change would have been lower, and we may consider that pre-industrial plants' $\delta^{13} \mathrm{C}$ values are reasonable approximations for vegetation at the time of the occupation of Kalavan 1, although the fact that they might have been slightly higher must be kept in mind. Using an enamel-diet ${ }^{13} \mathrm{C}$ enrichment factor of $+14.1 \%$ (Cerling and Harris, 1999), the expected mean value for a pure $C_{3}$ diet should be close to $-11.3 \%$ in enamel. According to the review by Kohn (2010), the $\delta^{13} \mathrm{C}$ values of $C_{3}$ plants extremely rarely exceed $-23 \%$ in modern environments, including those that thrive under a wide range of mean annual precipitation (1-3700 mm/yr), mean annual temperature $\left(-13.5\right.$ to $\left.28.4{ }^{\circ} \mathrm{C}\right)$ and altitude $(-391$ to $4900 \mathrm{~m})$. Consequently the value of $-7.7 \%$ in enamel may be considered as the absolute cut-off value for a pure $C_{3}$ diet in pre-industrial times. This estimation is similar to the value of -7 to $8 \%$ that was given in Cerling et al. (1997).

Variations of moderate amplitude $(1-2 \%)$ have been documented on a seasonal scale for $C_{3}$ plants' $\delta^{13} \mathrm{C}$ values, the highest values occurring in dry seasons and/or during the summer and the lowest in wet seasons and/or during the winter (Smedley et al., 1991; Hartman and Danin, 2010). In the case of vertical mobility towards higher elevations in the summer, the altitude effect on plant $\delta^{13} \mathrm{C}$ values may also apply. Carbon isotope discrimination during the photosynthesis of $C_{3}$ plants was found to decrease with increasing altitude, due to changes in temperature and atmospheric pressure, although a substantial genotypic component to this variation was also shown (Körner et al., 1988, 1991). In the study area, the bottom of the Kura Valley lies at $300 \mathrm{~m}$, while the alpine meadows are situated at an altitude of $2100-2200 \mathrm{~m}$, although during cold episodes of the Upper Pleistocene alpine meadows would have been lower (Adler and Tushabramishvili, 2004). In Körner et al. (1988), a linear regression between altitude and plant carbon isotope values shows an increase of $1.5 \%$ from $400 \mathrm{~m}$ to $2500 \mathrm{~m}$ above sea level. An increase of comparably modest amplitude could therefore be expected in the $\delta^{13} \mathrm{C}$ values of the alpine meadows compared to the valley pastures. The extent to which this pattern would be counterbalanced by differences in the relative abundance of $C_{3} / C_{4}$ at high and low elevations would depend on the relative abundance of $\mathrm{C}_{4}$ in the lowlands in winter.

\section{Materials and methods}

\subsection{Level 7, paleosurface $7 d 3$}

Taphonomic and geomorphological analyses of the Paleolithic layer 7 have shown disturbances, including bioturbation, light runoff and vertical dispersion (approximately $10 \mathrm{~cm}$ ), which are probably linked to repeated seasonal freezing-melting phenomena alternatively compressing and decompressing the soil (Montoya et al., 2013). However, a colluvial phenomenon from the mountain slope allowed for a quick burial of the paleosurface $7 \mathrm{~d} 3$. The latter appears to be well preserved, with several anthropic structures, among which three hearths, lithic concentrations, ochred areas and three heaps of faunal remains were found (Montoya et al., 2013). The tooth remains that were analyzed in this study are from the two principal faunal concentrations from paleosurface 7d3 (FG 23-24 and H32 [Fig. 3]).

\subsection{The sampled specimens}

Six lower tooth rows were selected for stable isotope analysis (Table 1). Considering laterality, wear stage and morphology, they all belong to different individuals. From the tooth eruption and wear patterns, they were attributed to Payne's age classes $2-3$ to 4-6 years (Payne, 1973). They all contained a second (M2) and a third molar (M3) except (KAL Ovis 01), for which only the M3 was analyzed because M2 was missing.

\subsection{Sampling procedures}

Sequential sampling was performed on the buccal side of the teeth, on the anterior lobe of the M2 and on the middle lobe of the M3 (Supplementary Online Material [SOM] 1). Each sample is located in the tooth crown using its distance from the enamel root junction (ERJ).

Enamel powders weighing 4-9 mg were treated for $4 \mathrm{~h}$ in $0.1 \mathrm{M}$ acid acetic $(0.1 \mathrm{ml} / \mathrm{mg}$ sample). Over treatment, the weight loss was approximately $28 \pm 4 \%$. Pre-treated enamel samples weighing 


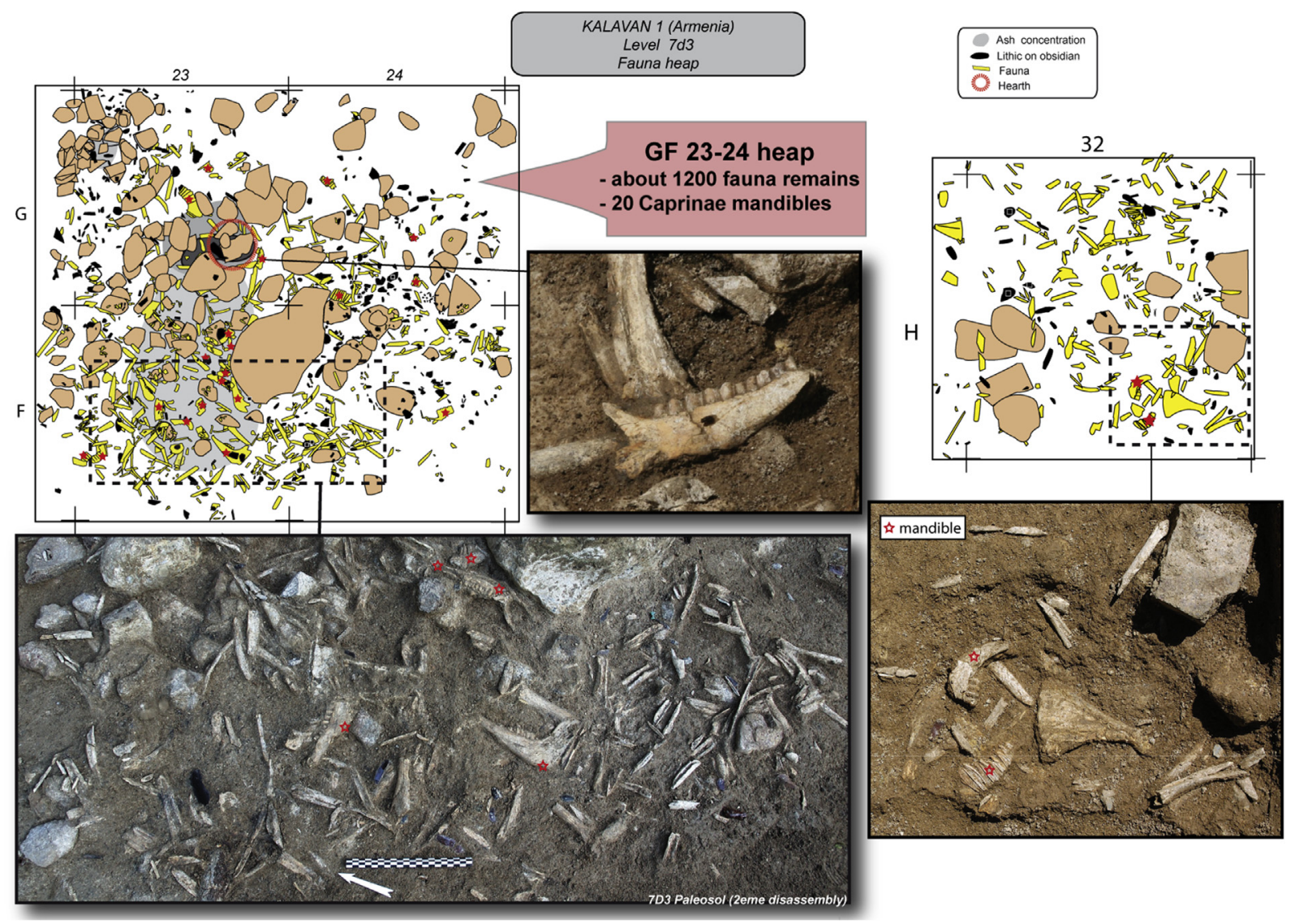

Figure 3. Spatial distribution of the mandible remains in paleosurface $7 \mathrm{~d} 3\left({ }^{\odot}\right.$ Computer graphics C. Montoya).

$\sim 600 \mu \mathrm{g}$ were analyzed on a Kiel IV device interfaced to a DeltaVAdvantage IRMS. Samples were reacted under vacuum with orthophosphoric acid $\left[\mathrm{H}_{3} \mathrm{PO}_{4}\right]$ at $70^{\circ} \mathrm{C}$ in individual vessels. The accuracy and precision of the measurements were checked using our laboratory calcium carbonate standard (Marbre LM normalized to the international standard NBS 19). Over the period of analysis of these bioapatite samples, 68 Marbre LM gave a mean $\delta^{13} \mathrm{C}$ value of $+2.05 \pm 0.02 \%(1 \sigma)$ (expected value $+2.13 \%$ ) and $\delta^{18} \mathrm{O}$ value of $-1.64 \pm 0.04 \%$ o $(1 \sigma)$ (expected value $-1.83 \%$ ). The mean analytical precision within each run was calculated from 7 to 8 measurements of Marbre LM in each analytical series, with averages of $0.03 \pm 0.01 \%$ for $\delta^{13} \mathrm{C}$ values and $0.08 \pm 0.02 \%$ for $\delta^{18} \mathrm{O}$ values. The results are expressed in V-PDB.

\section{Results}

The results from the stable carbon and oxygen isotope measurements are shown in Fig. 4. The sequences of the $\delta^{18} \mathrm{O}$ and $\delta^{13} \mathrm{C}$ values along the tooth crown show a pattern that is close to a sinusoidal variation, which reflects seasonal rhythmicity. The $\delta^{18} \mathrm{O}$ values range from $0.8 \%$ to $-10.4 \%$ in the M2s (with an amplitude of intra-tooth variation from $6.9 \%$ to $10.2 \%$ ) and from $-0.7 \%$ to $-11.0 \%$ in the M3s (with an amplitude of intra-tooth variation from $6.4 \%$ to $10 \%$ ). The $\delta^{13} \mathrm{C}$ values range from $-6 \%$ to $-10.4 \%$ o (with an amplitude of intra-tooth variation from $2.1 \%$ to $3.8 \%$ ) in the second molars and from $-6.5 \%$ to $-10.2 \%$ in the third molars (with an amplitude of intra-tooth variation from $2.3 \%$ to $3.3 \%$ ).

Over the (M2-M3) sequence, five landmarks are observed that correspond with optimum (highest or lowest) $\delta^{18} \mathrm{O}$ values (Fig. 5). Because the timing of the formation of the M2 and M3 overlaps in sheep (Weinreb and Sharav, 1964), event 2 may be represented twice, occurring both on the lowest (the latest formed) part of the M2 crown and on the highest (the earliest formed) part of the unworn M3 crown. This only occurs in KAL Ovis 04, which is the youngest specimen (Payne's E stage) with very slight tooth wear on the M3. In other individuals, tooth wear caused the loss of event 2 in the M3 (see SOM 1). The sequences that were measured over the M2 and M3 span two complete annual cycles. The optimum $\delta^{18} \mathrm{O}$ and $\delta^{13} \mathrm{C}$ values for each event are given in Table 2.

Intra-tooth variations in the $\delta^{18} \mathrm{O}$ and $\delta^{13} \mathrm{C}$ sequences are opposed, in contradiction to what would be expected for seasonal changes in pasture $\delta^{13} \mathrm{C}$ values on a local scale, whether it is due to

Table 1

Wild sheep specimens included in this study.

\begin{tabular}{|c|c|c|c|c|c|c|}
\hline Sample & Year & Square & Inventory no & Side & Dental stage (Payne, 1973) & Age \\
\hline KAL Ovis.01 & 2008 & G23 & 481 & Left & $\mathrm{F}$ & $3-4$ years \\
\hline KAL Ovis.02 & 2009 & $\mathrm{~F} 23$ & 3324 & Right & $\mathrm{F}$ & $3-4$ years \\
\hline KAL Ovis.03 & 2009 & E22 & $3384-170$ & Left & $\mathrm{F}$ & $3-4$ years \\
\hline KAL Ovis.04 & 2009 & $\mathrm{H} 32$ & $3387-170$ & Right & $\mathrm{E}$ & $2-3$ years \\
\hline KAL Ovis.05 & 2008 & F23 & $456-457$ & Right & $\mathrm{F}$ & $3-4$ years \\
\hline KAL Ovis.06 & 2008 & G23 & 526 & Right & $G$ & 4-6 years \\
\hline
\end{tabular}



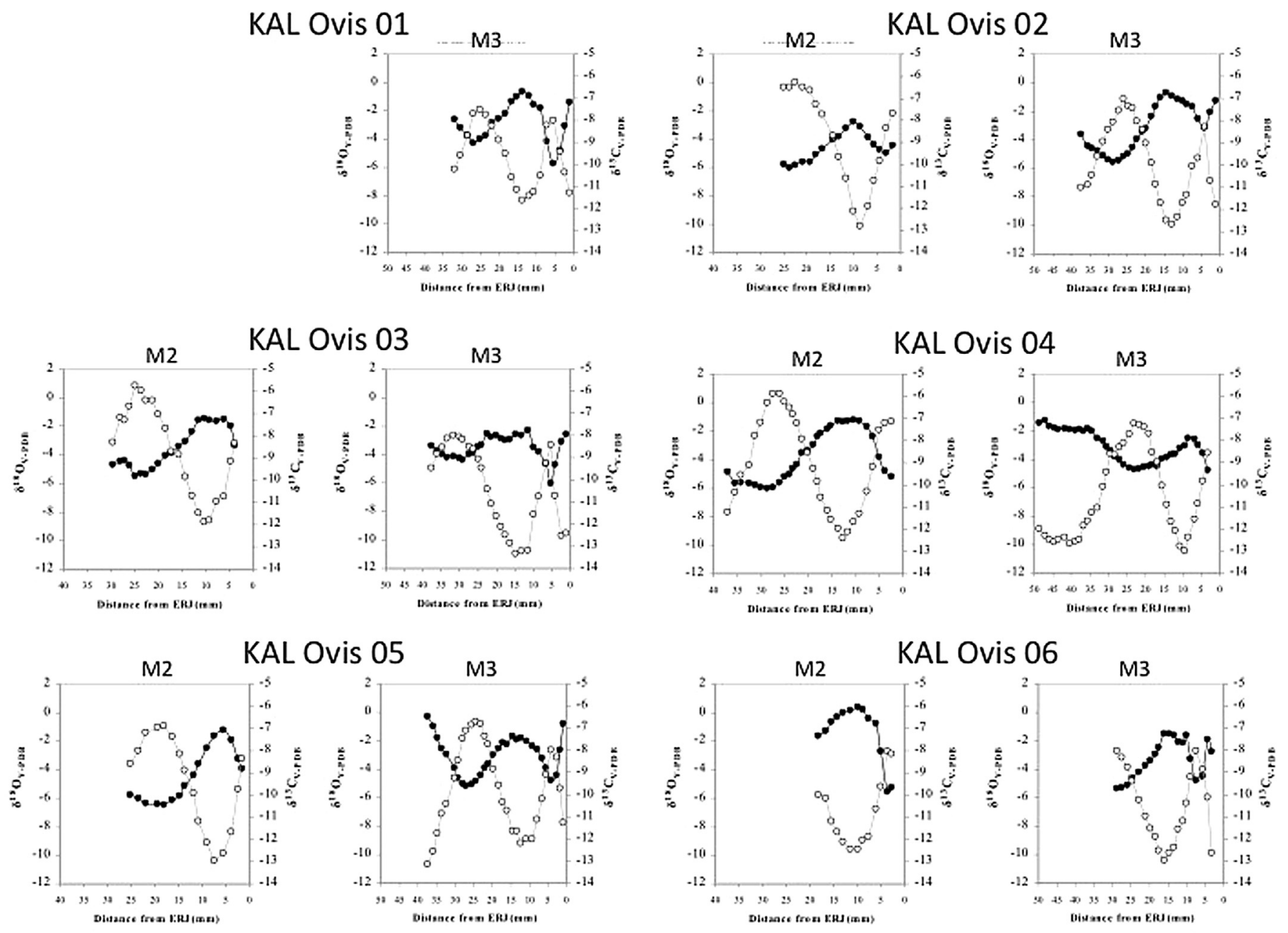

Figure 4. Results from the sequential analysis of carbon $\left(\delta^{13} \mathrm{C}\right)$ and oxygen $\left(\delta^{18} \mathrm{O}\right)$ isotope composition in second (M2) and third molars (M3).

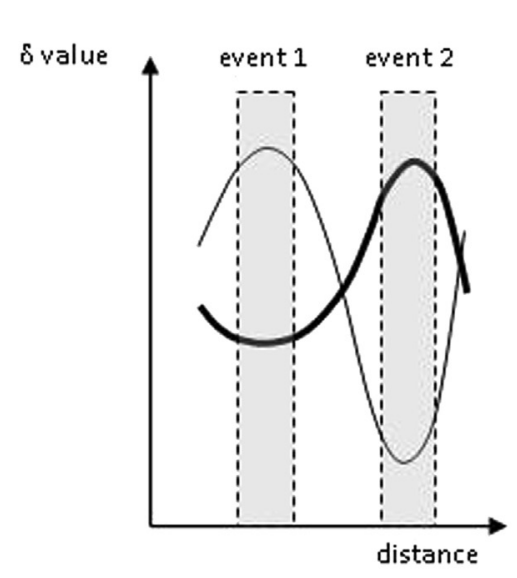

M2

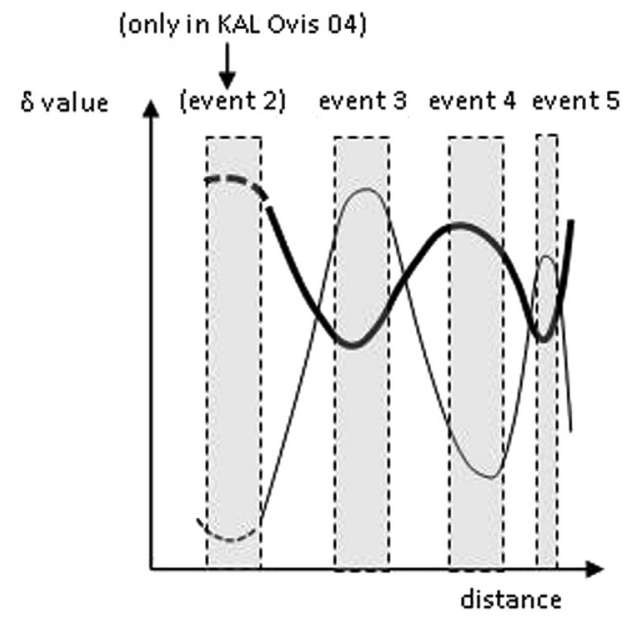

M3

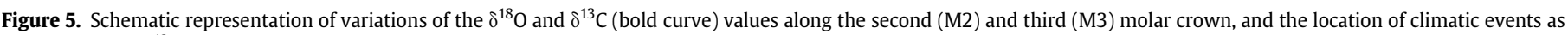
reflected in the $\delta^{18} \mathrm{O}$ values. 
Table 2

Optimum $\delta^{18} \mathrm{O}$ and $\delta^{13} \mathrm{C}$ values measured for each event (as defined in Fig. 6).

\begin{tabular}{|c|c|c|c|c|c|c|c|c|c|c|}
\hline \multirow[t]{3}{*}{ Sample } & \multicolumn{4}{|c|}{ M2 } & \multicolumn{6}{|c|}{ M3 } \\
\hline & \multicolumn{2}{|c|}{ Event 1} & \multicolumn{2}{|c|}{ Event 2} & \multicolumn{2}{|c|}{ Event 3} & \multicolumn{2}{|c|}{ Event 4} & \multicolumn{2}{|c|}{ Event 5} \\
\hline & $\delta^{18} \mathrm{Omax}$ & $\delta^{13} \mathrm{Cmin}$ & $\delta^{18} \mathrm{Omin}$ & $\delta^{13} \mathrm{Cmax}$ & $\delta^{18} \mathrm{Omax}$ & $\delta^{13} \mathrm{Cmin}$ & $\delta^{18} \mathrm{Omin}$ & $\delta^{13} \mathrm{Cmax}$ & $\delta^{18} \mathrm{Omax}$ & $\delta^{13} \mathrm{Cmin}$ \\
\hline KAL Ovis 01 & - & - & - & - & -1.9 & -9.0 & -8.3 & -6.7 & -2.7 & -10.0 \\
\hline KAL Ovis 02 & 0.0 & -10.2 & -10.2 & -8.1 & -1.2 & -9.9 & -9.9 & -6.7 & -3.1 & -8.3 \\
\hline KAL Ovis 03 & 0.8 & -9.8 & -8.7 & -7.2 & -2.7 & -9.1 & -11.0 & -7.8 & -3.3 & -10.2 \\
\hline KAL Ovis 04 & 0.6 & -10.1 & -9.5 & -7.1 & -1.5 & -9.3 & -10.4 & -7.9 & - & - \\
\hline KAL Ovis 05 & -0.9 & -10.4 & -10.4 & -7.1 & -0.7 & -9.6 & -9.2 & -7.4 & -2.6 & -9.3 \\
\hline KAL Ovis 06 & - & - & -9.6 & -6.0 & - & - & -10.4 & -7.2 & -2.7 & -9.3 \\
\hline Mean & 0.1 & -10.1 & -9.7 & -7.1 & -1.6 & -9.4 & -9.9 & -7.3 & -2.9 & -9.4 \\
\hline Range & 1.7 & 0.6 & 1.7 & 1.0 & 2.0 & 0.9 & 2.7 & 1.2 & 0.7 & 1.9 \\
\hline
\end{tabular}

the changing relative proportions of $C_{3} / C_{4}$ plants, or to changes in plant $\delta^{13} \mathrm{C}$ values. In both cases, this would lead to higher $\delta^{13} \mathrm{C}$ values during the warmer seasons. The opposing pattern that was observed in the wild sheep from Kalavan 1 most probably reflects vertical mobility. Similarly, opposed variations were measured in mountain sheep (Ovis canadensis) from a western North America site that dated to the Fremont period (ca AD 1100 to 1350; Fisher and Valentine, 2013).

Given the uncertainties that are exposed above concerning the $\delta^{18} \mathrm{O}$ values of summer water sources in high elevation sites and the occurrence of $\mathrm{C}_{4}$ plants in the Kura Valley in the Late Glacial period, two scenarios may be proposed to explain the opposing variations that are observed in the $\delta^{18} \mathrm{O}$ and $\delta^{13} \mathrm{C}$ sequences:

(1) In the first scenario, the lower $\delta^{18} \mathrm{O}$ values would reflect summer temperatures and water sources from high elevations. The altitude effect would lower the $\delta^{18} \mathrm{O}$ values in summer precipitations, while snow melt could also contribute with ${ }^{18} \mathrm{O}$-depleted water, both factors acting in opposition to the seasonal temperature effect. However, it must be noted that these combined factors could lead to a significant reduction in the amplitude of variation on the annual scale, but probably not to the point of reversal of the pattern. Considering the high amplitude of intra-tooth variation (up to $10 \%$ ), a reversal of the pattern (i.e., the lowest values $\delta^{18} \mathrm{O}$ corresponding to the summer instead of the winter seasons) would imply a significant contribution of considerably depleted water in the summer, potentially from the melting of glacial ice. In this scenario, events 2 and 4 would reflect summertime in the alpine meadows. The associated high $\delta^{13} \mathrm{C}$ values (that comprised between -8 and $-6 \%$ ) are sometimes higher than the absolute cut off values for a pure $C_{3}$ diet $(-7.7 \%$ ), even though only $C_{3}$ plants can thrive at these elevations. In this scenario, slightly higher $\delta^{13} \mathrm{C}$ values for plants in the Late Glacial period may be argued to explain this difference.

(2) In the second scenario, glacial ice melt did not contribute significantly to the summer water source at high elevation sites, and the combined effect of altitude and contribution of snow melt is not important enough to reverse the seasonal pattern in the $\delta^{18} \mathrm{O}$ values due to the temperature effect. In this scenario, events 1, 3 and 5 reflect summertime, while events 2 and 4 reflect wintertime. The higher $\delta{ }^{13} \mathrm{C}$ values in the winter (over the cut off value for a pure $C_{3}$ diet) reflect the occurrence of small amounts of $\mathrm{C}_{4}$ plants in the Kura Valley $-\mathrm{C}_{4}$ Chenopodiaceae, which are typical fodder plants, may have been preferentially grazed by the wild sheep - while the $C_{4}$ plants were absent at the high elevations sites in summer. In summertime, the $\delta^{13} \mathrm{C}$ values that comprised between -10 and $-9 \%$, may reflect a modest altitude effect.

\section{Discussion}

\subsection{A systematic pattern of vertical mobility}

The pattern of vertical mobility is observed in all specimens and, at least, over two consecutive years (M2-M3). Although the number of analyzed individuals is low, within this sample seasonal vertical mobility may be seen as a systematic behavioral pattern. Modern Armenian mouflons migrate from the lowlands to spend the summer in the high mountains in search of more abundant food. They return to the lowlands in autumn and spend the winter there, escaping from the harsh conditions and scarcity of vegetal resources. Similar reasons must have driven the vertical mobility that has been observed in the Late Glacial wild sheep.

\subsection{A marked seasonality of birth}

The sequences of the $\delta^{18} \mathrm{O}$ values that were measured in all of the individuals' M2 and M3s are compared in Figure 6. The great similarity between individuals in the position of optimum values in tooth crowns suggests a strong seasonality of birth (Bryant et al., 1996; Fricke and O'Neil, 1996; Balasse et al., 2003). A constrained season of births goes together with seasonal mobility over a wide range because long distance altitudinal mobility would increase the vulnerability of lactating females and young animals. This constraint may, therefore, influence the timing of births, so when mobility is initiated, both females and young mouflons are strong enough to endure the experience. This would also imply a reduction in the birth period. The reproductive cycle of modern Armenian mouflons is indeed strongly tuned to their pattern of altitudinal mobility. The rutting season occurs in the lowland areas between mid-October and the end of November, with the peak activity in the first part of November when adult females and males are less dispersed. The females give birth in early spring in the lowland areas before the migration to the high altitudes; although some of them may spend the summer at the valley bottom if the young calves or mothers fail to reach adequate weight before the migration (Dinnik, 1910; Sarkisov, 1944; Vereshchagin, 1959; Valdez, 2008; Khorozyan et al., 2009; Talibov et al., 2009).

\subsection{Specimens accumulated over a short period of time}

The faunal assemblage that was recovered at Kalavan 1 may have been the result of hunting events that were conducted over a limited number of episodes. The archaeological evidence at the site argues for seasonal, short-term occupations. The spatial distribution and volume of the archaeological vestiges, the documented steps in knapping activities, the weak thermo-alteration of the hearth soils and stone surfaces, and the absence of important rearrangement of the fireplaces all suggest a relatively brief 

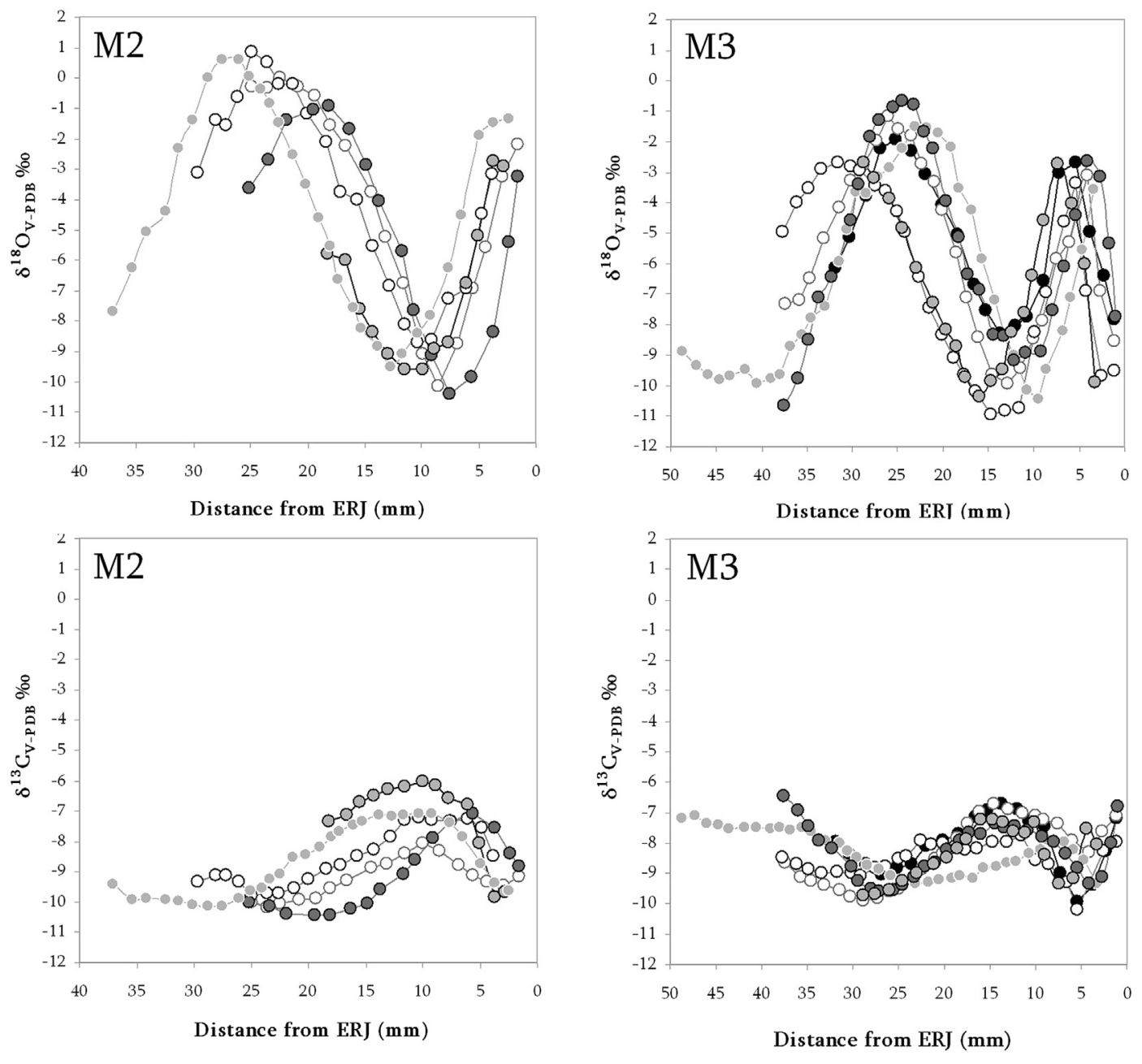

- KAL Ovis $01 \quad$ - KAL Ovis $02 \quad$ - KAL Ovis 03

- - KAL Ovis $04 \quad-$ - KAL Ovis $05 \quad-0-$ KAL.Ovis 06

Figure 6. Sequential $\delta^{18} \mathrm{O}_{\mathrm{V} \text {-PDB }}$ and $\delta^{13} \mathrm{C}_{\mathrm{V} \text {-PDB }}$ values in all second and third molars.

occupation of the site (Bălășescu et al., 2016; Montoya et al., 2013). The densest concentration (GF 23-24 in 7d3 layer) was composed of a compact and homogeneous mound of fauna remains in an ashy, sedimentary matrix. No intercalated solifluxion flow in the fauna heaps was observed during the excavation, while this phenomenon was clearly identified within the $7 \mathrm{~d} 2$ layer.

The $\delta^{18} \mathrm{O}$ and $\delta^{13} \mathrm{C}$ values that were measured in all of the specimens are compared in Figure 6. Events 1 to 5 (as referred to in Fig. 5) span a two-year sequence of time. In all five of the individuals, this sequence spans the same period of life. Considering that the attributed ages at death are close to each other (2-3 years for KAL Ovis 04; 3-4 years for KAL Ovis 01, Ovis 02, Ovis 03 and Ovis 05 ; 4-6 years for KAL Ovis 06; Table 1) and considering the extreme case of a unique hunting event, the sequences that are measured in these specimens may refer to the same years for KAL Ovis 01 , Ovis 02 , Ovis 03 and Ovis 05 and to very close years for the remaining two sheep. In this case, and supposing minimal interannual variability in environmental $\delta^{18} \mathrm{O}$ and $\delta^{13} \mathrm{C}$ signals over a four year time period, a great similarity would be expected in the $\delta^{18} \mathrm{O}$ and $\delta^{13} \mathrm{C}$ values. Although similar stable isotope values would not necessarily demonstrate close contemporariness between individuals, great dissimilarity would invalidate the hypothesis.

Inter-individual variability is not solely a matter of the vegetal environment and climate that defines the isotopic history; individual feeding behavior, metabolism and physiology (tooth growth and mineralization rate) also influence the integration of the input signal in enamel and, consequently, the final maximum and minimum values of the sequence. For this reason, interindividual variability within a pool of individuals with the same stable isotope history may exist. Elements for comparison may be found in modern reference studies. Two reference sets of domestic sheep were considered. The first one consists of 10 modern sheep that were raised on the island of Rousay (Orkney archipelago, Scotland [Balasse et al., 2009, 2012]). All of the specimens were born a few weeks apart, were raised in the same cohort, grazing on the same terrestrial pasture with access to the same water sources, and they were slaughtered on the same day. In these specimens' $\mathrm{M} 2 \mathrm{~s}$, in which the isotopic sequences encompassed a winter and a summer event, inter-individual variability was $1.9 \%$ and $1.1 \%$, respectively, in optimal $\delta^{18} \mathrm{O}$ values ( $n=10$ [Balasse et al., 2012]) and $1.2 \%$ and $1.4 \%$, respectively, in optimal $\delta^{13} \mathrm{C}(n=6$ [Balasse et al., 2009]). The difference in the amplitude of variation was $1.3 \%$ for the $\delta^{18} \mathrm{O}$ values, and $1 \%$ the for $\delta^{13} \mathrm{C}$ values. In the second reference set (Blaise and Balasse, 2011), inter-annual variability over four years is introduced. This set includes eight sheep that were raised in the subalpine region of Southern France. The sheep were born between 1998 and 2001 and slaughtered in May 2004. They grazed on the rangelands near the farm all year round and 
Table 3

Amplitude of the $\delta^{18} \mathrm{O}$ and $\delta^{13} \mathrm{C}$ sequences during recorded events.

\begin{tabular}{|c|c|c|c|c|c|c|c|c|}
\hline \multirow[t]{2}{*}{ Sample } & \multicolumn{4}{|c|}{ Amplitude in $\delta^{18} \mathrm{O}$} & \multicolumn{4}{|c|}{ Amplitude in $\delta^{13} \mathrm{C}$} \\
\hline & Events 1 to 2 & Events 2 to 3 & Events 3 to 4 & Events 4 to 5 & Events 1 to 2 & Events 2 to 3 & Events 3 to 4 & Events 4 to 5 \\
\hline KAL Ovis 01 & - & - & 6.4 & 5.6 & - & - & 2.3 & 3.3 \\
\hline KAL Ovis 02 & 10.2 & 9.0 & 8.7 & 6.8 & 2.1 & 1.8 & 3.2 & 1.6 \\
\hline KAL Ovis 03 & 9.5 & 6.0 & 8.3 & 7.7 & 2.6 & 1.9 & 1.3 & 2.4 \\
\hline KAL Ovis 04 & 10.1 & 8.0 & 8.9 & - & 3.0 & 2.2 & 1.4 & - \\
\hline KAL Ovis 05 & 9.5 & 9.7 & 8.5 & 6.5 & 3.3 & 2.5 & 2.2 & 2.0 \\
\hline KAL Ovis 06 & - & - & - & 7.7 & - & - & - & 2.1 \\
\hline Max & 10.2 & 9.7 & 8.9 & 7.7 & 3.3 & 2.5 & 3.2 & 3.3 \\
\hline Min & 9.5 & 6.0 & 6.4 & 5.6 & 2.1 & 1.8 & 1.3 & 1.6 \\
\hline Range & 0.7 & 3.7 & 2.5 & 2.1 & 1.2 & 0.7 & 1.9 & 1.7 \\
\hline
\end{tabular}

were provided with water from a source near the town. In the M2s, where the isotopic sequences encompassed a summer and a winter event, inter-individual variability in optimal $\delta^{18} \mathrm{O}$ values was $1.5 \%$ $(n=5)$ and $1.2 \%$ o $(n=3)$, respectively; in the M3s, in which the isotopic sequences also encompassed a summer and a winter event, inter-individual variability in the optimal $\delta^{18} \mathrm{O}$ values was $2.5 \%$ $(n=5)$ and $1.6 \%(n=6)$, respectively.

In the Kalavan 1 mouflon, the inter-individual variability in the $\delta^{13} \mathrm{C}$ and $\delta^{18} \mathrm{O}$ values that were recorded in the different summer and winter events are shown in Table 3 . In the $\delta^{18} \mathrm{O}$ values, interindividual variability is $1.7 \%, 1.7 \%, 2 \%, 2.7 \%$ and $0.7 \%$ in events $1,2,3,4$ and 5 , respectively, while in $\delta^{13} \mathrm{C}$, it is $0.6 \%, 1 \%, 0.9 \%, 1.2 \%$ and $1.9 \%$, respectively. The inter-individual variability in the amplitude of variation between two successive events is $0.7 \%$, $3.7 \%$, $2.5 \%$ and $2.1 \%$ in $\delta^{18} \mathrm{O}$ values and $1.2 \%, 0.7 \%, 1.9 \%$ and $1.7 \%$ in $\delta^{13} \mathrm{C}$ values between events 1 to 2,2 to 3,3 to 4 and 4 to 5 , respectively (Table 3 ). All of these indicators of inter-individual variability are of similar magnitude to those observed in the modern reference sets of sheep that were born in the same year or a few years apart, which supports the hypothesis that these sheep had similar environmental life histories and were possibly born within a short time period. This is in agreement with the hypothesis of a short time accumulation of sheep remains at the campsite.

\section{Conclusions}

Although a larger sample size would be desirable, the outcomes of this study are significant for the paleoethology of ancient wild sheep populations from northeastern Armenia (Lesser Caucasus region) during Late Glacial times. They contribute indirectly to the understanding of the pattern of occupation of mountain territories by Epigravettian communities. On the paleoethological side, for the first time, vertical mobility on a seasonal scale was demonstrated for the wild sheep that were recovered at Kalavan 1 . This was reflected in opposed variation in the $\delta^{13} \mathrm{C}$ and $\delta^{18} \mathrm{O}$ sequences, which suggests that winter was spent in the lowlands and summer on the highland meadows. The pattern of vertical mobility in Late Glacial wild sheep is similar to the one that was described for modern Armenian mouflons and may have been driven by similar reasons, pushing wild sheep towards higher elevation in summer in search of better pastures and pushing them downwards with the arrival of winter and reduced accessibility to highland meadows because of the snow cover. Additionally, a strong seasonality of birth for Late Glacial wild sheep was suggested, in agreement with the strong constraint that was represented by the pattern of a wide range in seasonal mobility.

From a methodological point of view, uncertainties remain in the interpretation of the $\delta^{18} \mathrm{O}$ sequences: would vertical mobility, in this context, lead to a reversal of the otherwise expected temperature-controlled pattern? This particular point should be addressed in the future as it would be relevant to any study that investigates the summer attendance at high elevation sites where glacial ice melt may contribute to the water pool. This interpretation would also directly influence determination of wild sheep birth season from $\delta^{18} \mathrm{O}$ sequences in teeth.

On the archaeological side, the pattern of seasonal altitudinal mobility of the wild sheep that were recovered at Kalavan 1 suggests that their availability near the site was restricted to certain times of the year during bi-annual migrations. The huntergatherers of Kalavan 1 scheduled wild sheep exploitation at specific periods of the year when the animals were crossing the altitudinal location of the site, which implies an awareness of wild herd mobility strategies. Further, a low inter-individual variability in the stable isotope sequences does not contradict other archaeological evidence in favor of the accumulation of these faunal remains over a short period of time. This new dataset strengthens the previous interpretations at Kalavan 1, which presents this hunting camp site within a wider and complex strategy of exploitation of the mountainous territories by Epigravettian communities, involving the acquisition of obsidian resources at high elevation sites after the thawing of the snow cover in spring to summer and carcass butchering for the collection of stores of animal products at Kalavan 1 (Montoya et al., 2013; Bălășescu et al., 2016, Fig. 2). This integrative study of animal behavior and the socio-economy of Epigravettian hunter-gatherers builds a picture of how two mobile trajectories met at Kalavan 1: a logistic nomadism by Paleolithic communities on the one hand and the seasonal altitudinal migration of wild sheep herds on the other.

\section{Acknowledgments}

The stable isotope analyses were performed at the Service de Spectrométrie de Masse Isotopique du Muséum national Histoire naturelle of Paris, France (SSMIM) with technical assistance by Joël Ughetto. This project was designed and supported by the European Research Council (ERC) Starting Grant "SIANHE"-GA 202881 directed by Dr. Marie Balasse, to which Dr. Carlos Tornero is linked by a postdoctoral fellowship. The excavations of Kalavan 1 were supported by the French Ministry of Foreign Affairs (mission Caucasus) and the Armenian branch of the Gfoeller Fund of America Corporation. We would like to thank Roman Hovsepyan (Institute of Archaeology and Ethnography of Erevan) for his useful discussions on the present day occurrence of $\mathrm{C}_{4}$ plants in the Kura Valley. The original version of this paper was greatly improved based on comments that were received from an anonymous reviewer.

\section{Supplementary Online Material}

Supplementary online material related to this article can be found at http://dx.doi.org/10.1016/j.jhevol.2016.05.001. 


\section{References}

Adler, D.S., Tushabramishvili, N., 2004. Middle Paleolithic patterns of settlement and subsistence in the southern Caucasus. In: Conard, N.J. (Ed.), Settlement Dynamics of the Middle Paleolithic and Middle Stone Age, vol. II. Kerns Verlag, Tübingen, pp. 91-133.

Akhani, H., Ghasemkhani, M., 2007. Diversity of photosynthetic organs in Chenopodiaceae from Golestan National Park (NE Iran) based on carbon isotope composition and anatomy of leaves and cotyledons. Nova Hedwigia 131, 265-277.

Akhani, H., Ziegler, H., 2002. Photosynthetic pathways and habitats of grasses in Golestan National Park (NE Iran), with an emphasis on the C4-grass dominated rock communities. Phytocoenologia 32, 455-501.

Balasse, M., Smith, B., Ambrose, S.H., Leigh, S., 2003. Determining sheep birth seasonality by analysis of tooth enamel oxygen isotope ratios: the Late Stone Age site of Kasteelberg (South Africa). J. Archaeol. Sci. 30, 205-215.

Balasse, M., Mainland, I., Richards, M.P., 2009. Stable isotope evidence for seasonal consumption of seaweed by modern and archaeological sheep in the Orkney archipelago (Scotland). Envi. Archaeol. 14, 1-14.

Balasse, M., Obein, G., Ughetto-Monfrin, J., Mainland, I., 2012. Investigating seasonality and season of birth in past herds: a reference set of sheep enamel stable oxygen isotope ratios. Archaeometry 54, 349-368.

Bălăşescu, A., Montoya, C., Gasparyan, B., Liagre, J., Chataigner, C., 2016. The Upper Paleolithic fauna from Kalavan-1 (Armenia): preliminary results. In: Archaeozoology of the Near East Marjan Mashkour (Editor); Mark Beech (Editor) with publisher as Oxbow Books, Oxford, see http://www.oxbowbooks.com/oxbow/ archaeozoology-of-the-near-east-9.html.

Bhatia, M.P., Das, S.B., Kujawinski, E.B., Henderson, P., Burke, A., Charette, M.A., 2011 Seasonal evolution of water contributions to discharge from a Greenland outlet glacier: insight from a new isotope-mixing model. J. Glaciol. 57, 929-941.

Blaise, E., Balasse, M., 2011. Seasonality and season of birth of modern and late Neolithic sheep from south-eastern France using tooth enamel $\delta^{18} \mathrm{O}$ analysis. J. Archaeol. Sci. 38, 3085-3093.

Bryant, J.D., Froelich, P.N., Showers, W.J., Genna, B.J., 1996. Biologic and climatic signals in the oxygen isotopic composition of Eocene-Oligocene equid enamel phosphate. Paleogeogr. Palaeoclimatol. Palaeoecol. 126, 75-89.

Cerling, T.E., Harris, J.M., 1999. Carbon isotope fractionation between diet and bioapatite in ungulate mammals and implications for ecological and paleoecological studies. Oecologia 120, 347-363.

Cerling, T.E., Wang, Y., Quade, J., 1993. Expansion of C4 ecosystems as an indicator of global ecological change in the late Miocene. Nature 361, 344-345.

Cerling, T.E., Harris, J.M., MacFadden, B.J., Leakey, M.G., Quade, J., Eisenmann, V., Ehleringer, J.R., 1997. Global vegetation change through the Miocene/Pliocene boundary. Nature 389, 153-158.

Chataigner, C., Gratuze, B., 2014a. New data on the exploitation of obsidian in the southern Caucasus (Armenia, Georgia) and eastern Turkey. Part 1: source characterization. Archaeometry 56, 25-47.

Chataigner, C., Gratuze, B., 2014b. New data on the exploitation of obsidian in the southern Caucasus (Armenia, Georgia) and eastern Turkey. Part 2: obsidian procurement from the Upper Palaeolithic to the Late Bronze Age. Archaeometry 56, 48-69.

D'Angela, D., Longinelli, A., 1991. Oxygen isotopes in living mammal's bone phosphate: further results. Chem. Geol. 86, 75-82.

Dinnik, N.Ya, 1910. Beasts of the Caucasus. Part 1. Kozlovsky's Press, Tbilisi: K.P. (In Russian).

Ehleringer, J.R., 2005. The influence of atmospheric $\mathrm{CO}_{2}$, temperature, and water on the abundance of $\mathrm{C}_{3} / \mathrm{C}_{4}$ taxa. In: Ehleringer, J.R., Cerling, T., Dearing, M.D. (Eds.), A History of Atmospheric $\mathrm{CO}_{2}$ and its Effects on Plants, Animals, and Ecosystems. Springer, New York, pp. 214-231.

Fisher, J.L., Valentine, B., 2013. Resource depression, climate change, and mountain sheep in the eastern Great Basin of western North America. Archaeol. Anthropol. Sci. 5, 145-157.

Fricke, H.C., O'Neil, J.R., 1996. Inter- and intra-tooth variation in the oxygen isotope composition of mammalian tooth enamel phosphate: implications for palaeoclimatological and palaeobiological research. Palaeogeogr. Palaeoclimatol. Palaeoecol. 126, 91-99.

Friedli, H., Lötscher, H., Oeschger, H., Siegenthaler, U., Stauffer, B., 1986. Ice cores record of the ${ }^{13} \mathrm{C} /{ }^{12} \mathrm{C}$ ratio of atmospheric $\mathrm{CO}_{2}$ in the past two centuries. Nature 324, 237-238.

Gasparyan, B., Kandel, A.W., Montoya, C., 2014. Living the high life: The Upper Paleolithic settlement of the Armenian highlands. In: Gasparyan, B., Arimura, M. (Eds.), Stone Age of Armenia. A Guide Book to the Stone Age Archaeology in the Republic of Armenia. Center for Cultural Resource Studies. Kanazawa University, pp. 107-131.
Gat, J.R., 1996. Oxygen and hydrogen isotopes in the hydrologic cycle. Annu. Rev Earth Planet. Sci. Lett. 24, 225-262.

Gonfiantini, R., Roche, M.-A., Olivry, J.-C., Fontes, J.-C., Zuppi, G.M., 2001. The altitude effect on the isotopic composition of tropical rains. Chem. Geol. 181, 147-167.

Hartman, G., Danin, A., 2010. Isotopic values of plants in relation to water availability in the Eastern Mediterranean region. Oecologia 162, 837-852.

Hatami, E., Khosravi, A.R., 2013. Mapping geographic distribution of $\mathrm{C}_{3}$ and $C_{4}$ species of the family Chenopodiaceae in Iran. Iran. J. Bot. 19, 263-276.

Hatté, C., Fontugne, M., Rousseau, D.-D., Antoine, P., Zöller, L., Tisnérat-Laborde, N. Bentlaleb, I., 1998. $\delta^{13} \mathrm{C}$ variations of loess organic matter as a record of the vegetation response to climatic changes during the Weichselian. Geology 26, 583-586.

Khorozyan, I.G., Weinberg, P.I., Malkhasyan, G., 2009. Conservation strategy for Armenian mouflon (Ovis lorientalis] gmelini Blyth) and Bezoar goat (Capra aegagrus Erxleben) in Armenia. In: Zazanashvili, N., Mallon, D. (Eds.), Status and Protection of Globally Threatened Species in the Caucasus. CEPF Biodiversity Investments in the Caucasus Hotspot 2004-2009, Tiblisi, pp. 37-45.

Kohn, M.J., 2010. Carbon isotope compositions of terrestrial $C_{3}$ plants as indicators of (paleo)ecology and (paleo)climate. Proc. Natl. Acad. Sci. 107, 19691-19695.

Kohn, M.J., Welker, J.M., 2005. On the temperature correlation of $\delta^{18} \mathrm{O}$ in modern precipitation. Earth Planet. Sci. Lett. 231, 87-96.

Kohn, M.J., Schoeninger, M.J., Valley, J.W., 1996. Herbivore tooth oxygen isotope composition: effects of diet and physiology. Geochim. Cosmochim. Acta 60 3889-3896.

Körner, C., Farquhar, G.D., Roksandic, Z., 1988. A global survey of carbon isotope discrimination in plants from high altitude. Oecologia 74, 623-632.

Körner, C., Farquahar, G.D., Wong, C., 1991. Carbon isotope discrimination by plants follows latitudinal and altitudinal trends. Oecologia 88, 30-40.

Land, L.S., Lundelius Jr., E.L., Valastro, S., 1980. Isotopic ecology of deer bones. Palaeogeogr. Palaeoclimatol. Palaeoecol. 32, 143-151.

Lee-Thorp, J.A., van der Merwe, N., 1987. Carbon isotope analysis of fossil bone apatite. S. Afr. J. Sci. 83, 712-715.

Longinelli, A., Selmo, E., 2003. Isotopic composition of precipitation in Italy: a first overall map. J. Hydrol. 270, 75-88.

Marino, B.D., McElroy, M.B., 1991. Isotopic composition of atmospheric $\mathrm{CO}_{2}$ inferred from carbon in $\mathrm{C}_{4}$ plant cellulose. Nature 349, 127-131.

Marino, B.D., McElroy, M.B., Salawitch, R.J., Spaulding, W.G., 1992. Glacial-to-interglacial variations in the carbon isotopic composition of atmospheric $\mathrm{CO}_{2}$. Nature 357, 461-466.

Montoya, C., Bălăşescu, A., Joannin, S., Ollivier, V., Liagre, J., Nahapetyan, S. Ghukasyan, R., Colonge, D., Gasparyan, B., Chataigner, C., 2013. The upper Palaeolithic site of Kalavan 1 (Armenia): An Epigravettian settlement in the Lesser Caucasus. J. Hum. Evol. 65, 621-640.

Payne, S., 1973. Kill-off patterns in sheep and goats: the mandibles from Asvan Kale. Anatolia Studies 23, 281-303.

Rao, Z.G., Chen, F.H., Zhang, X., Xu, Y.B., Xue, Q., Zhang, P.Y., 2012. Spatial and temporal variations of $C_{3} / C_{4}$ relative abundance in global terrestrial ecosystem since the Last Glacial and its possible driving mechanisms. Chin. Sci. Bull. 57, 4024-4035.

Rozanski, K., Araguas-Araguas, L., Gonfiantini, R., 1993. Isotopic patterns in modern global precipitation. In: Swart, P.K., Lohmann, K.C., McKenzie, J., Savin, E. (Eds.), Climate Change in Continental Isotopic Records. American Geophysical Union, Geophysical Monograph 78, Washington DC, pp. 1-36.

Sarkisov, A.A., 1944. Nasonov's Armenian mouffon Ovis ophion armeniana. Trudy Erevanskogo Zoologicheskogo Parka 3, 5-52 (In Russian).

Smedley, M., Dawson, T., Comstock, J., Donovan, L., Sherill, D., Cook, C.M. Ehleringer, I., 1991. Seasonal carbon isotope discrimination in a grassland community. Oecologia 85, 314-320.

Talibov, T.H., Weinberg, P.I., Mammadov, I.B., Mammadov, E.N., Talibov, S.T., 2009. Conservation strategy of the Asiatic mouflon (Ovis [orientalis] gmelini Blyth) and the Bezoar goat (Capra aegagrus Erxleben) in Azerbaijan. In: Zazanashvili, N. Mallon, D. (Eds.), Status and Protection of Globally Threatened Species in the Caucasus. CEPF Biodiversity Investments in the Caucasus Hotspot 2004-2009, Tiblisi, pp. 46-52.

Valdez, R., 2008. Ovis orientalis. In: IUCN Red List of Threatened Species. Version 2010.4. www.iucnredlist.org (accessed 20.01.15.).

Vereshchagin, N.K., 1959. Mammals of the Caucasus. USSR Academic Science Press, Moscow and Lenigrad (In Russian).

Vogel, I.C., Fuls, A., Ellis, R.P., 1978. The geographical distribution of Kranz grasses, S. Afr. J. Sci. 74, 209-215.

Weinreb, W., Sharav, Y., 1964. Tooth development in sheep. Am. J. Vet. Res. 25, $891-908$.

Winter, K., 1981. $C_{4}$ plants of high biomass in arid regions in Asia: occurrence of $C_{4}$ photosynthesis in Chenopodiaceae and Polygonaceae from the Middle East and USSR. Oecologia 48, 100-106. 